\title{
The Stabilization of Weathered Dolerite Aggregates with Cement, Lime, and Lime Fly Ash for Pavement Construction
}

\author{
Felix N. Okonta and Oluwapelumi O. Ojuri \\ Department of Civil Engineering Science, University of Johannesburg, Auckland Park, Johannesburg 2006, South Africa \\ Correspondence should be addressed to Oluwapelumi O. Ojuri; ojurip@yahoo.com
}

Received 29 June 2013; Revised 15 November 2013; Accepted 18 November 2013; Published 5 February 2014

Academic Editor: Jun Zhang

Copyright ( 2014 F. N. Okonta and O. O. Ojuri. This is an open access article distributed under the Creative Commons Attribution License, which permits unrestricted use, distribution, and reproduction in any medium, provided the original work is properly cited.

\begin{abstract}
An experimental program was performed on weathered dolerite specimens stabilized by adding varying percentages of cement (4, $8,12$, and 16$) \%$ and lime ( 6 and 12) \% and a combination of lime and fly ash (6\% lime $+12 \%$ Fly ash and $12 \%$ lime $+12 \%$ Fly ash) $\%$ by dry weight of soil. The strength was examined under three different curing methods, namely, membrane curing (MBC), alternate moist-air curing (MAC), and water curing (WAC), by conducting unconfined compressive strength (UCS) tests. Simple polynomial and linear functions (regression models) were used to define the relationships between the variables investigated. Membrane curing (MBC) gave results close enough to the water curing (WAC) to indicate that it can be confidently used on the field during pavement construction. From the results obtained, for class B (interurban collector and major rural roads) pavement construction, addition of $8 \%$ cement was recommended for road base construction with stabilized WDA. Also the addition of $12+12 \%$ Lime and Fly Ash was recommended for road subbase construction with stabilized WDA. Stabilized WDA against the prejudiced myths would perform satisfactorily for base and subbase construction in both heavily trafficked and low volume roads with economic quantities of cement, lime, and fly ash in South Africa.
\end{abstract}

\section{Introduction}

Aggregates can be considered to have poor, marginal, or premium quality depending on the properties of the source material, the processing operation, and the end resulting engineering characteristics. Generally poor quality aggregates are not suitable for road construction and marginal quality aggregates do not comply with many traditional contract specifications. However by stabilising/modifying marginal quality aggregates performance properties similar to or better than a premium quality aggregates can be achieved $[1,2]$. Many local highway authorities do not have accessible premium quality aggregate sources and have adopted stabilisation/modification for road construction using locally produced aggregate. This enables a sustainable paving program utilising local resources and improved energy management. As a result of the increasing demands for new aggregate quarries, the general texture of earth's surface has been steadily deteriorating, causing environmental concerns. The use of weathered dolerite aggregates might help meet the increasing demands and slow down any detrimental effects on the environment [3]. Stabilisation of pavements has been practised widely in South Africa for more than 29 years; however, it has until recent times mainly been confined to subgrade layers or for rehabilitation and maintenance of existing aggregate layers [4]. Following many research and development projects in many parts of the world and years of successful application, chemical modification of an aggregate of marginal quality is now an accepted process that can produce a material which has structural and performance properties equal to or better than those of premium quality aggregates [5]. Aggregate stabilisation or modification is a proven pavement construction technique which utilises local aggregates to enable pavement construction at often significantly reduced costs and without adversely affecting the pavement's performance. Naturally occurring road building materials suitable for the higher-quality upper strata of road pavements (base and subbase layers) are systematically being depleted, resulting in the haulage of alternative materials over increasing distances or the introduction of more expensive commercially manufactured (i.e., crushed) materials, thus negating the basis of the local pavement design philosophy. 
For this reason the naturally occurring materials have to be better assessed for their effective utilisation. The weathered rock most widely used for road construction purposes in South Africa, yet also notorious for its variability and propensity to marginal behaviour, is dolerite [6].

Dolerite is a medium grained igneous rock with composition similar to basalt and is usually found in dykes or sills. The physical and chemical properties of dolerite make it a versatile material, which can be used as a crushed aggregate in producing concrete and as a road subbase [7]. Dolerite is a difficult rock to deal with because it can possess good physical and mechanical properties while its chemical and mineralogical compositions could be problematic. And in most cases, fresh dolerite has sufficient strength to meet any engineering requirement. [8] reported that cement stabilized dolerite aggregates in South Africa have uniaxial compressive strengths that tend to range between 1.3 and $2.7 \mathrm{MPa}$ for $3 \%$ cement content. [9] states that dolerites tend to weather inwards, that is, from the top down and from the sides inwards. This implies that the more weathered and softer material will be closer to the surface. Materials close to the surface, when used in construction, tend to deteriorate more rapidly than the unweathered material within a quarry. From the studies of $[10,11]$ lime has been recommended stabiliser for dolerite. [10] recommends that a PI $>10$ should be treated with lime. He also recommended that a PI $<10$ should be treated with cement and a PI lying between 10 and 25 should be treated with lime and cement. Curing is the process of controlling the rate and extent of moisture loss from concrete during cement hydration. Concrete curing methods can be divided into four categories, namely, water curing, membrane curing, application of heat, and miscellaneous. Some stabilisers need adequate curing time in order to reach sufficient strength. This is evident in the investigation carried out by [12]. A number of guidelines for determining which stabilization technique is suitable for a particular soil have been suggested [13-17] on the basis of the stabilization responses of the major soil components. However, the actual choice of the most appropriate stabilizing agent and the quantity of the agent required are usually based on the 7-day unconfined compressive strength of the stabilized soil.

\section{Materials and Methods}

2.1. Elemental, Mineralogical Composition, and Particle Size Distribution. The naturally occurring highly weathered dolerite aggregates investigated in this work were obtained from Rooikraal Quarry (AfriSam) in Johannesburg, near Boksburg. The material was a light to dark brown relatively fine, sandy gravel. Elemental and mineralogical analyses were performed at the Geology Laboratory University of Johannesburg to determine properties of the dolerite test specimen, cement, lime, and fly ash. X-ray Fluorescence (XRF) analysis including major elements was carried out on crushed $<26.5 \mathrm{~mm}$ sample. The X-ray Fluorescence analyzer was used for the elemental analysis of the WDA sample. X-ray diffraction (XRD) analysis was done on crushed $<26.5 \mathrm{~mm}$ sample and $<0.002 \mathrm{~mm}$ fractions. The X-ray diffractometer was used to determine the mineral composition of the

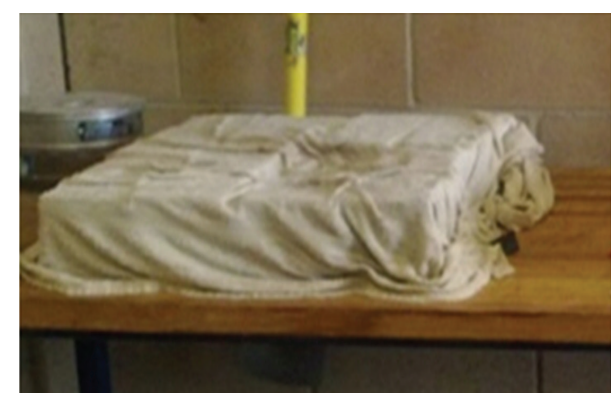

Figure 1: Membrane curing (MBC).

WDA sample. Elemental and mineralogical analyses were performed on whole samples of the cement, lime, and fly ash. Particle size distribution analysis was performed on weathered dolerite aggregate specimen according to the South African National Institute for Transport and Road Research of the Council for Science and Industrial Research (CSIR), Technical Methods for Highways, part 1 [18].

\subsection{Sample Preparation, Compaction, and Unconfined Com-} pression. An experimental program was performed on weathered dolerite specimens stabilized by adding varying percentages of cement $(4,8,12,16) \%$, lime $(6,12) \%$, and a combination of lime and fly ash (6\% lime $+12 \%$ fly ash, $12 \%$ lime $+12 \%$ fly ash) $\%$ by dry weight of soil. A total of two hundred and eighty-eight stabilized dolerite cubes $(100 \mathrm{~mm} \times$ $100 \mathrm{~mm} \times 100 \mathrm{~mm}$ ) were tested to study the effect of varying additive percentages, curing methods, durability conditions, and initial moulding water contents. The specimens were left to equilibrate for 24 hours prior to compaction. The maximum dry density and optimum water content for the unstabilized sample and each mix were determined by $100 \%$ modified AASTHO compaction test in accordance with [19]. From the compaction test on the unstabilized dolerite, optimum moisture content (OMC) of $12 \%$ and maximum dry density (MDD) of $1860 \mathrm{~kg} / \mathrm{m}^{3}$ were used to cast the stabilised dolerite cubes. The strength and durability were examined under three different curing methods, namely, membrane curing (MBC); moist-air curing (MAC) and water curing (WAC) ponding, by conducting unconfined compressive strength (UCS) tests. The unconfined compressive strength (UCS) test was conducted on stabilized specimens, compacted into the $100 \mathrm{~mm}$ by $100 \mathrm{~mm}$ mould to the reference modified AASTHO MDD and OMC, cured for 7 days in accordance with [18].

2.3. Curing. For the membrane curing (MBC) (Figure 1), compacted specimens were cured for 7 days at a relative humidity of 95 to 100 percent and temperature of $22^{\circ} \mathrm{C}$ to $25^{\circ} \mathrm{C}$ in a curing room. The specimens were covered by permeable hessian bags (foamed plastic bags) and water was sprinkled constantly on the cover over the selected curing period. The moist-air curing (MAC) entails using a wet cloth to keep the cubes moist for a day and, the next day and the cubes were dried, and the following day the cubes were kept moist again. This was also done for a period of seven days and they were 


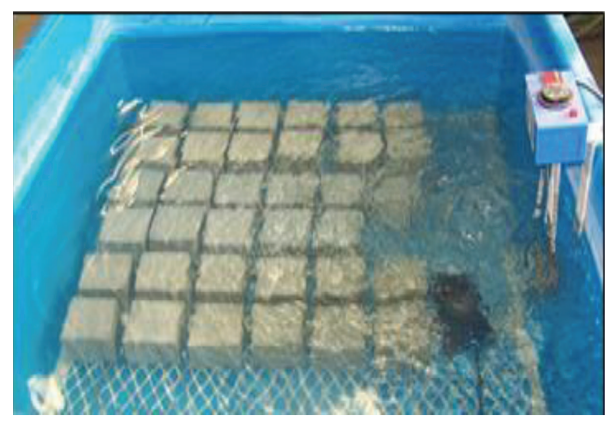

FIgURE 2: Water curing (WAC).

checked every few hours. The cubes were submerged in the curing bath for a period of seven days for the water curing (WAC) (Figure 2).

2.4. Wet-Dry Durability Test. After being cured for a period of seven days using three different curing methods, the cubes were dried in the oven at a temperature of $30-35^{\circ} \mathrm{C}$ for a period of 24 hours. After 24 hours, half the cubes were tested dry for maximum strength (dry durability condition) using the compression testing machine and the other half are submerged in water for 2 days and tested wet for minimum strength (soaked durability condition). The dry and wet durability conditions were used as simple durability indices.

2.5. Simulating Wet-Dry (W-D) Cycles for Wider Variations of Binder Proportions. A more detailed durability test, alternate wet-dry cycles using the procedure reported in [20], was used to simulate W-D cycles. This was done for a wider range of binder proportions, namely, $4 \%, 8 \%, 12 \%$, and $16 \%$ cement contents; $6 \%$ lime and 6\% fly ash; 6\% Lime and $12 \%$ Fly Ash; 6\% Lime and 18\% Fly Ash; 6\% Lime and 24\% Fly Ash; 12\% Lime and 12\% Fly Ash; 12\% Lime and 18\% Fly Ash; $12 \%$ Lime and 24\% Fly Ash; 12\% Lime and 30\% Fly Ash. One W-D cycle consisted of placing a specimen in an oven having a temperature of $71^{\circ} \mathrm{C}\left(160^{\circ} \mathrm{F}\right)$ for 24 hours and then submerging it in portable water for 24 hours at room temperature. W-D cycles were applied on cured samples. The number of W-D cycles considered in this study was 0 and 12 . At the end of each specified cycle, specimens were tested for unconfined compressive strength using the INSTRON 5500R compression machine.

2.6. Initial Moulding Water Content. The effect of initial moulding water content on mobilised UCS was investigated for $4 \%$ and $8 \%$ cement content using $8 \%, 12 \%, 15 \%$, and $18 \%$ water contents. The unconfined compression strength (UCS) test was conducted on stabilized specimens.

All the tests were repeated on two specimens and the results reflect the average determined from tests on identical specimen.

\section{Results and Discussions}

3.1. Composition and Particle Size Distribution of Dolerite. The chemical composition of the dolerite was determined
TABLE 1: Chemical composition of dolerites as determined by XRF.

\begin{tabular}{lc}
\hline Compound name & Concentration in fresh dolerite (Mass \%) \\
\hline $\mathrm{SiO}_{2}$ & 50 \\
$\mathrm{Al}_{2} \mathrm{O}_{3}$ & 18 \\
$\mathrm{Fe}_{2} \mathrm{O}_{3}$ & 11 \\
$\mathrm{CaO}$ & 9 \\
$\mathrm{MgO}$ & 5 \\
$\mathrm{Na}_{2} \mathrm{O}$ & 3.2 \\
$\mathrm{TiO}_{2}$ & 1.1 \\
$\mathrm{~K}_{2} \mathrm{O}$ & 0.82 \\
$\mathrm{P}_{2} \mathrm{O}_{5}$ & 0.33 \\
$\mathrm{MnO}$ & 0.17 \\
$\mathrm{SO}$ & 0.076 \\
$\mathrm{~L} . \mathrm{O} . \mathrm{I}$ & 1.4 \\
$\mathrm{Total}$ & $\mathbf{1 0 0 . 0 9 6}$ \\
\hline Trace elements & \\
\hline $\mathrm{Ba}$ & 0.039 \\
$\mathrm{Cl}$ & 0.025 \\
$\mathrm{Sr}$ & 0.023 \\
$\mathrm{Zr}$ & 0.011 \\
\hline
\end{tabular}

TABLE 2: Mineral composition of dolerite by XRD.

\begin{tabular}{lc}
\hline Mineral & \multicolumn{2}{c}{ Percentage composition (\%) } \\
\hline & XRD mineralogy (whole sample) $(\%)$ \\
Plagioclase & 46 \\
Pyroxene (augite) & 20 \\
Olivine & 11 \\
Amphibole & 4 \\
Quartz & 7 \\
Chlorite & 2 \\
\hline & XRD clay mineralogy $(<0.002 \mathrm{~mm})$ \\
Kaolinite & 64 \\
Smectite & 10 \\
Feldspar & 26 \\
\hline
\end{tabular}

by X-ray Fluorescence, and the results are shown in Table 1. Table 1 indicates that $\mathrm{SiO}_{2}$ generally accounts for 50 percent of the dolerite. The dolerite also contains notable amounts of aluminium oxide $\left(\mathrm{Al}_{2} \mathrm{O}_{3}\right)$, iron oxide $\left(\mathrm{Fe}_{2} \mathrm{O}_{3}\right)$, and calcium oxide $(\mathrm{CaO})$. The mineral composition of the dolerites was determined by X-ray diffraction. The results are given in Table 2. X-ray diffraction indicated that calcic plagioclase was the predominant mineral followed by pyroxene (normally augite). Table 2 shows the presence of kaolinite clay mineral and a low smectite group composition. Table 3 indicates that $\mathrm{CaO}$ and $\mathrm{SiO}_{2}$ account for $59.8 \%$ and $19.3 \%$, respectively, of the ordinary Portland cement (OPC). The OPC also has $\mathrm{Al}_{2} \mathrm{O}_{3}$ and $\mathrm{Fe}_{2} \mathrm{O}_{3}$ as notable compounds with $3.67 \%$ and $3.44 \%$. X-ray diffraction indicated that calcium silicate was the predominant mineral followed by lamite (Table 4). From Table $5 \mathrm{CaO}$ accounts for $79.7 \%$ of the Lime and Portlandite is the predominant mineral as indicated in Table 6 . The chemical composition of the Fly ash used is given in Table 7 with 
TABLE 3: Chemical composition of ordinary portland cement as determined by XRF.

\begin{tabular}{lc}
\hline Compound name & Concentration in cement (mass \%) \\
\hline $\mathrm{SiO}_{2}$ & 19.3 \\
$\mathrm{Al}_{2} \mathrm{O}_{3}$ & 3.67 \\
$\mathrm{Fe}_{2} \mathrm{O}_{3}$ & 3.44 \\
$\mathrm{CaO}$ & 59.8 \\
$\mathrm{MgO}$ & 2.18 \\
$\mathrm{SO}_{3}$ & 3.34 \\
$\mathrm{Na}_{2} \mathrm{O}$ & 0.165 \\
$\mathrm{TiO}_{2}$ & 0.597 \\
$\mathrm{~K}_{2} \mathrm{O}$ & 0.218 \\
$\mathrm{P}_{2} \mathrm{O}_{5}$ & 0.0897 \\
$\mathrm{MnO}$ & 0.237 \\
\hline $\mathrm{Trace}$ elements & \\
\hline $\mathrm{Sr}$ & 0.023 \\
$\mathrm{Zr}$ & 0.011 \\
\hline
\end{tabular}

TABLE 4: Mineral composition of ordinary Portland cement by XRD.

\begin{tabular}{lc}
\hline \multicolumn{2}{c}{$\begin{array}{c}\text { XRD mineralogy (\%) } \\
\text { Mineral }\end{array}$} \\
\hline Calcium silicate & 40 \\
Laminate & 19 \\
Calcium aluminium oxide & 16 \\
Brownmillerite & 13 \\
Periclase & 8 \\
Gypsum & 4 \\
\hline
\end{tabular}

TABLE 5: Chemical composition of lime as determined by XRF.

\begin{tabular}{lc}
\hline Compound name & Concentration in lime (mass \%) \\
\hline $\mathrm{SiO}_{2}$ & 1.69 \\
$\mathrm{Al}_{2} \mathrm{O}_{3}$ & 0.325 \\
$\mathrm{Fe}_{2} \mathrm{O}_{3}$ & 0.384 \\
$\mathrm{CaO}$ & 79.7 \\
$\mathrm{MgO}$ & 2.40 \\
$\mathrm{MnO}$ & 1.12 \\
$\mathrm{SO}_{3}$ & 0.104 \\
$\mathrm{~K}_{2} \mathrm{O}$ & 0.0504 \\
$\mathrm{Cl}$ & 0.0267 \\
$\mathrm{P}_{2} \mathrm{O}_{5}$ & 0.00788 \\
\hline
\end{tabular}

TABLE 6: Mineral composition of lime by XRD.

\begin{tabular}{lc}
\hline & XRD mineralogy (whole sample) (\%) \\
Mineral & Percentage composition (\%) \\
\hline Portlandite & 96.3 \\
Calcite & 3.7 \\
\hline
\end{tabular}

$\mathrm{SiO}_{2}$ and $\mathrm{Al}_{2} \mathrm{O}_{3}$ accounting for $56.4 \%$ and $37.1 \%$, respectively. $\mathrm{CaO}$ with $3.69 \%$ and $\mathrm{Fe}_{2} \mathrm{O}_{3}$ with $2.95 \%$ are also notable. From Table 8 the Fly ash contains quartz, $63.8 \%$, and mullite, $36.2 \%$,
TABLE 7: Chemical composition of fly ash as determined by XRF.

\begin{tabular}{lc}
\hline Compound name & Concentration in lime (mass \%) \\
\hline $\mathrm{SiO}_{2}$ & 56.40 \\
$\mathrm{Al}_{2} \mathrm{O}_{3}$ & 37.10 \\
$\mathrm{Fe}_{2} \mathrm{O}_{3}$ & 2.95 \\
$\mathrm{CaO}$ & 3.69 \\
$\mathrm{MgO}$ & 1.02 \\
$\mathrm{SO}_{3}$ & 0.400 \\
$\mathrm{Na}_{2} \mathrm{O}$ & 0.257 \\
$\mathrm{~K}_{2} \mathrm{O}$ & 0.826 \\
$\mathrm{TiO}_{2}$ & 1.61 \\
$\mathrm{P}_{2} \mathrm{O}_{5}$ & 0.525 \\
$\mathrm{Trace}_{2}$ ements & \\
\hline $\mathrm{Zn}$ & 0.00855 \\
$\mathrm{Ga}$ & 0.00546 \\
$\mathrm{As}$ & 0.00469 \\
$\mathrm{Rb}$ & 0.00487 \\
$\mathrm{Sr}$ & 0.0892 \\
$\mathrm{Y}$ & 0.0134 \\
$\mathrm{Zr}$ & 0.0364 \\
$\mathrm{Ba}$ & 0.0810 \\
$\mathrm{~Pb}$ & 0.0116 \\
\hline
\end{tabular}

TABLE 8: Mineral composition of fly ash by XRD.

\begin{tabular}{lc}
\hline & XRD mineralogy (\%) \\
Mineral & Percentage composition (\%) \\
\hline Quartz & 63.8 \\
Mullite & 36.2 \\
\hline
\end{tabular}

as minerals. The result of the particle size distribution for the unstabilized dolerite is presented in Figure 3.

From the results of the plot of the particle size distribution (Figure 3), the dolerite consists of 51\% gravel, 20\% sand, and $26 \%$ fine $(<0.075 \mathrm{~mm}$ size). The liquid limit obtained using the Casagrande apparatus was 25.3. The plasticity index (PI) obtained from the grading modulus was maximum PI = 13. The AASHTO classification for the weathered dolerite aggregate sample used was A-2-6.

3.2. Compaction Characteristics. The result of the compaction test for cement stabilized weathered dolerite aggregate (WDA) specimens is presented in Figure 4. The maximum dry density of the unstabilized dolerite was $1860 \mathrm{~kg} / \mathrm{m}^{3}$ and the optimum moisture content $12 \%$. The maximum dry density increased and the optimum moisture content decreased with increasing cement content. Relationships have been established between maximum dry density (MDD) and cement content, and optimum moisture content (OMC) and cement content by regression analysis with polynomial and linear equations of 0.9463 and 0.9866 coefficients of determination, respectively (Figures 5 and 6).

The result of the compaction test for lime stabilized weathered dolerite aggregate (WDA) specimens is presented in Figure 7. The maximum dry density decreased and the 


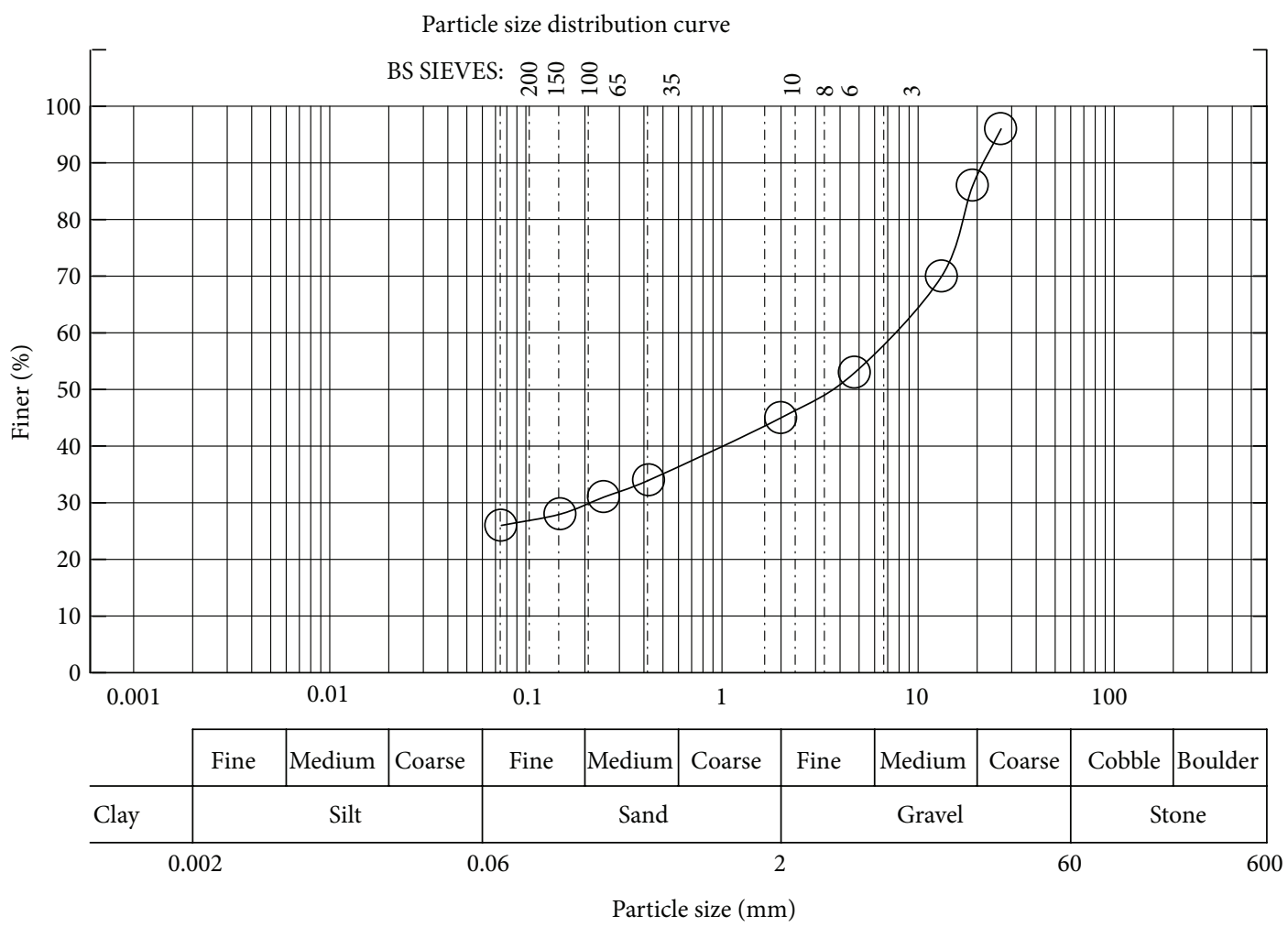

Figure 3: The grading curve for the weathered dolerite aggregate (WDA) sample.

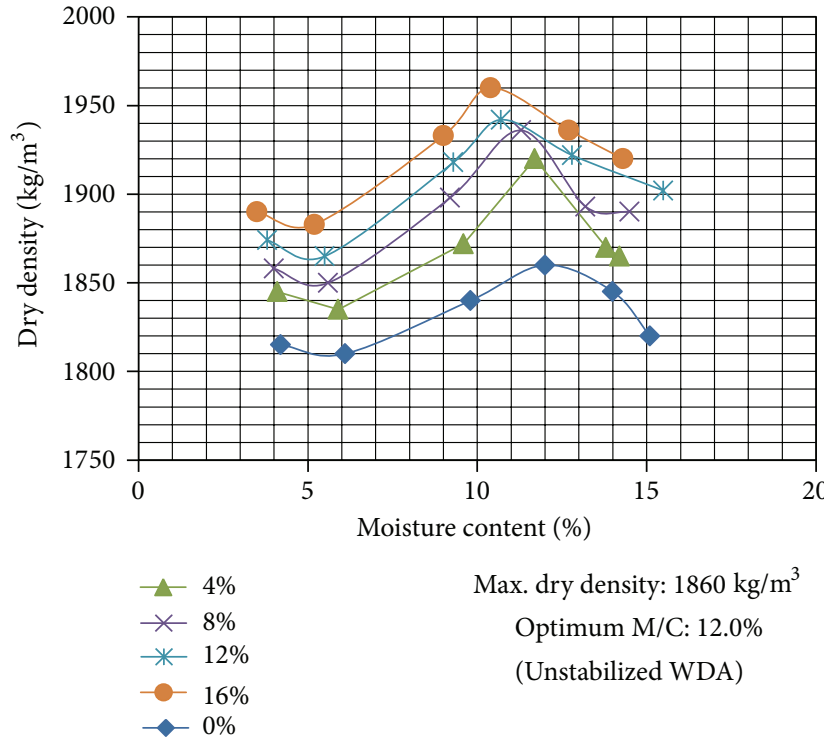

FIgURE 4: Compaction curve of fresh and stabilized WDA specimens at different contents of cement.

optimum moisture content increased with increasing lime content. Relationships have been established between maximum dry density (MDD) and lime content, and optimum moisture content (OMC) and lime content by regression analysis with a linear and polynomial equations of 0.9908 and 1 coefficients of determination, respectively (Figures 8 and 9).

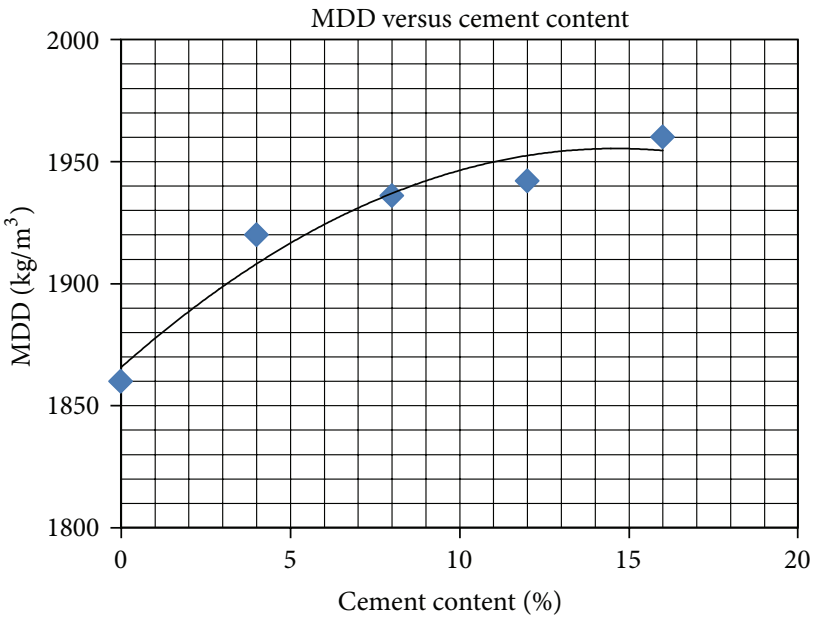
$\rightarrow$ MDD versus $\%$ cement
_ Poly. (MDD versus \% cement)
$y=-0.4196 x^{2}+12.264 x+1865.8$ $R^{2}=0.9463$

FIGURE 5: Relationship between maximum dry density and cement content for stabilized WDA.

The result of the compaction test for lime and fly ash stabilized weathered dolerite aggregate (WDA) specimens is presented in Figure 10. The maximum dry density decreased and the optimum moisture content increased with increasing cement content in a similar manner to lime stabilized WDA.

After conducting compaction tests on cement, lime, and combinations of lime, and fly ash and obtaining different 


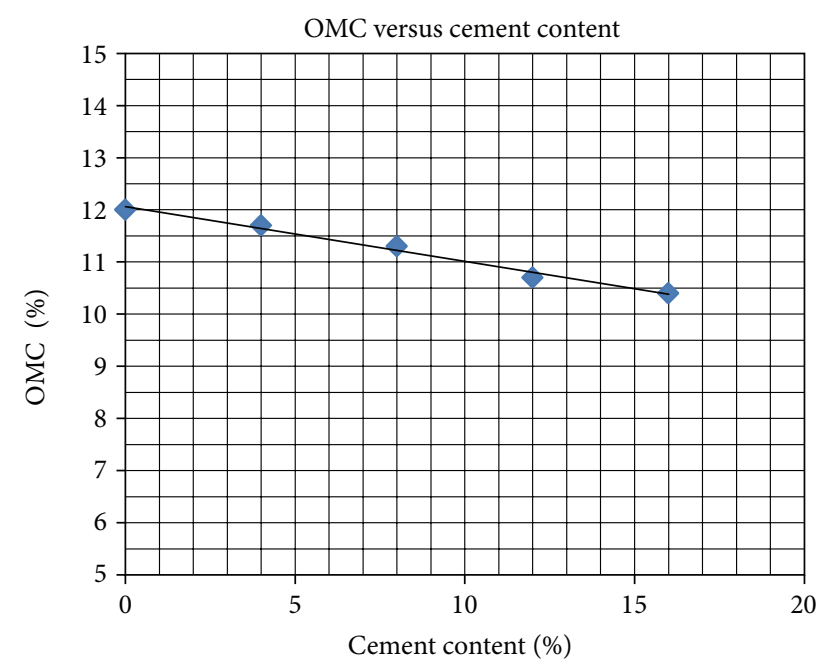

$\begin{array}{lc}\text { OMC versus cement content } & y=-0.105 x+12.06 \\ \text { Linear (OMC versus cement content) } & R^{2}=0.9866\end{array}$

FIGURE 6: Relationship between optimum moisture content and cement content for stabilized WDA.

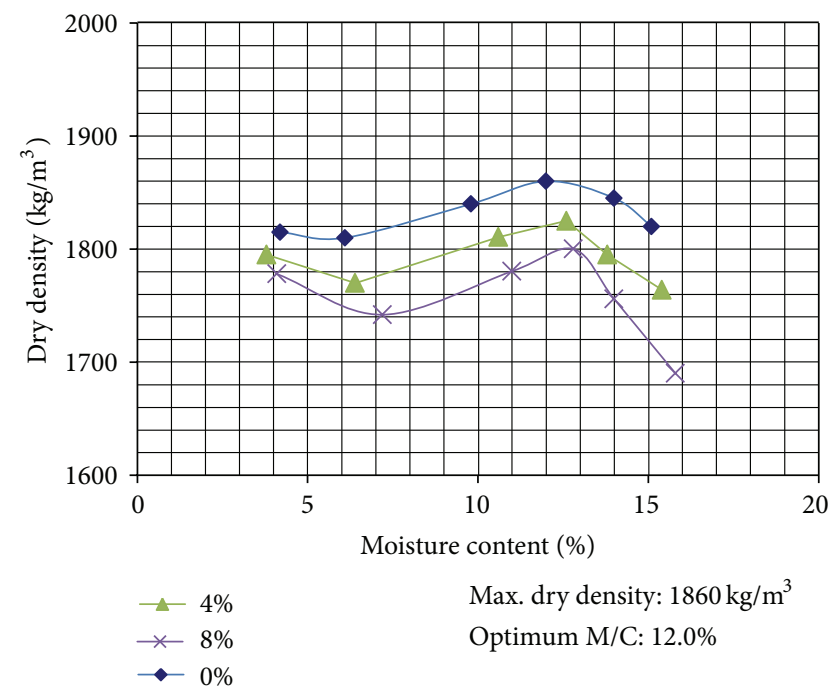

FIgURE 7: Compaction curve of unstabilized and stabilized WDA specimens at different contents of lime.

results of OMC and MDD, reference OMC and MDD values of $12 \%$ and $1860 \mathrm{~kg} / \mathrm{m}^{3}$ were used to cast the cubes for the unconfined compression tests.

\subsection{Effect of Curing on UCS and Young's Modulus for the Different Durability Conditions}

3.3.1. Cement Stabilization $(4,8,12$, and $16 \%$ Cement). The result of the unconfined compressive strength tests for the specimens tested dry (dry durability condition) is plotted in Figure 11. The UCS for the stabilized WDA increased with increase in cement content for the three curing methods with generally higher strength values for water curing. The values of the UCS for the membrane curing (MBC) for the

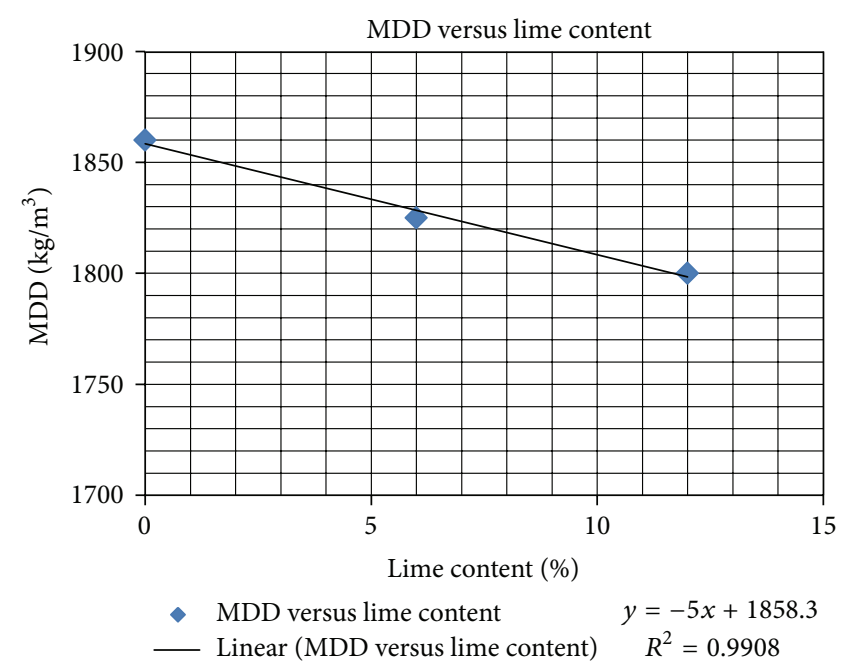

FIGURE 8: Relationship between maximum dry density and lime content for stabilized WDA.

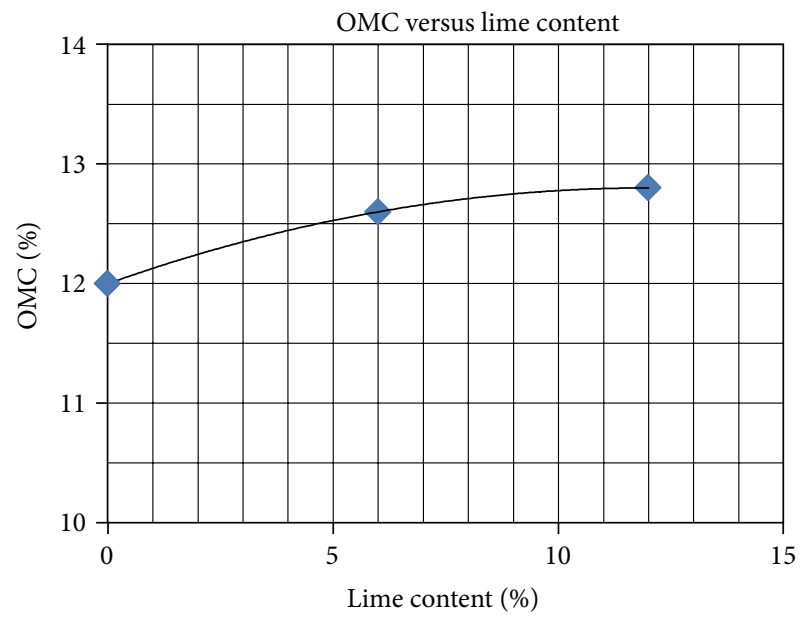

$\begin{array}{lc}\text { OMC versus lime content } & y=-0.0056 x^{2}+0.1333 x+12 \\ \text { - Poly. (OMC versus lime content) } & R^{2}=1\end{array}$

FIGURE 9: Relationship between optimum moisture content and lime content for stabilized WDA.

various cement percentages can be seen to be close to those for the water curing (WAC). Polynomial equations with high coefficients of determination $\left(0.96 \leq R^{2} \leq 0.99\right)$ relating UCS to cement content are displayed in the chart (Figure 11). Equation (1) is the best equation relating UCS to cement content $(C)$. For the stabilized WDA it was observed that, at $4 \%$ cement, all three curing methods supplied enough water for cement hydrolysis and cement hydration; therefore there was no remarkable change in the UCS value (Figure 11). As the cement content has increased, the demand for water has also increased. The porosity decreases with increasing cement content and this makes it difficult for the flow of water to get to the centre of the specimen with high cement contents. The specimens tested after two days of soaking (soaked durability 


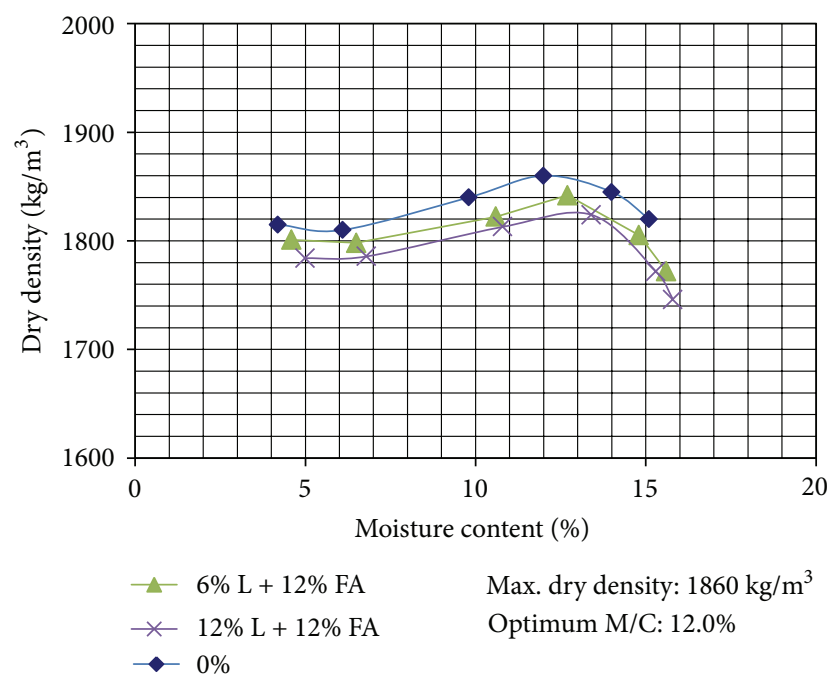

FIGURE 10: Compaction curve of unstabilized and stabilized WDA specimens at different contents of lime and fly ash.

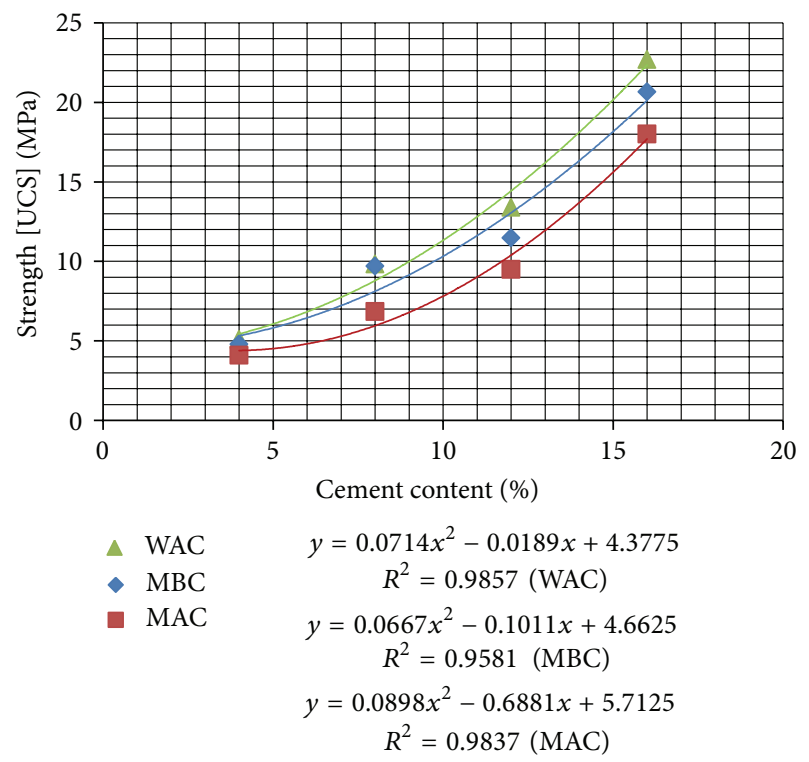

FIgURE 11: UCS for different cement contents (dry durability condition).

condition) gave lower UCS values for each of the cement content investigated:

$$
\mathrm{UCS}=0.0714 C^{2}-0.0189 C+4.3775 \quad\left(R^{2}=0.9857\right) .
$$

Young's modulus is a measure of stiffness of the stabilized WDA obtained as the ratio of uniaxial stress over the uniaxial strain from the unconfined compressive strength tests. The result of increasing Young's modulus with increase in cement content is presented in Figure 12 with correlation equations, for the three curing methods (WAC, MBC, and MAC) with the dry durability condition. The trend of the WAC and MBC is similar to the UCS versus cement content plot. Equation

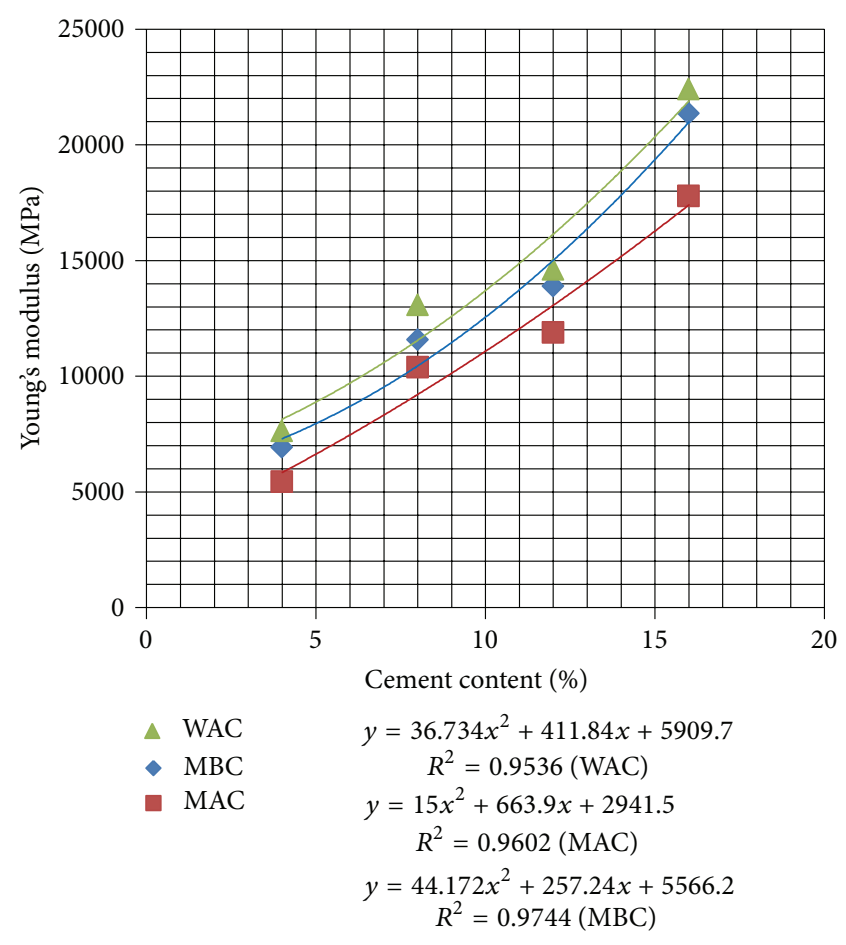

FIGURE 12: Young's modulus of different cement contents (dry durability conditions).

(2) is the best equation relating Young's modulus $(E)$ to cement content $(C)$. From the results of the UCS and Young's modulus for the various cement contents, a relationship has been established between Young's Modulus $(E)$ and UCS in Figure 13. Equation (3) with a coefficient of determination of 0.9978 is proposed as an approximate expression to predict the Young's modulus of stabilized WDA from the unconfined compressive strength. Equation (3) is for the MBC curing. The other two curing methods also gave similar correlation indices. Equation (3) gave similar values to the one proposed by [5] for cement treated aggregates:

$$
\begin{gathered}
E=44.172 C^{2}+257.24 C+5566.2 \quad\left(R^{2}=0.9744\right), \\
E=2042.7 \mathrm{UCS}^{0.7756} \quad\left(R^{2}=0.9978\right) .
\end{gathered}
$$

3.3.2. Lime Stabilization (6 and 12\% Lime). All the cubes with the $6 \%$ lime (dry and soaked durability condition) content failed before, during, and after curing. From literature [10, 11], lime needs an adequate amount of clay content to react and form bonds. Because this project deals with dolerite rock which has little clay content, lime was not able to react with the water and form bonds, thus resulting in the cubes failing. From Figure 14 it can be seen that the strength for all three curing methods increases with increase in lime content with WAC being the most effective and MAC the least. All the cubes with the $12 \%$ lime (soaked durability condition) content 


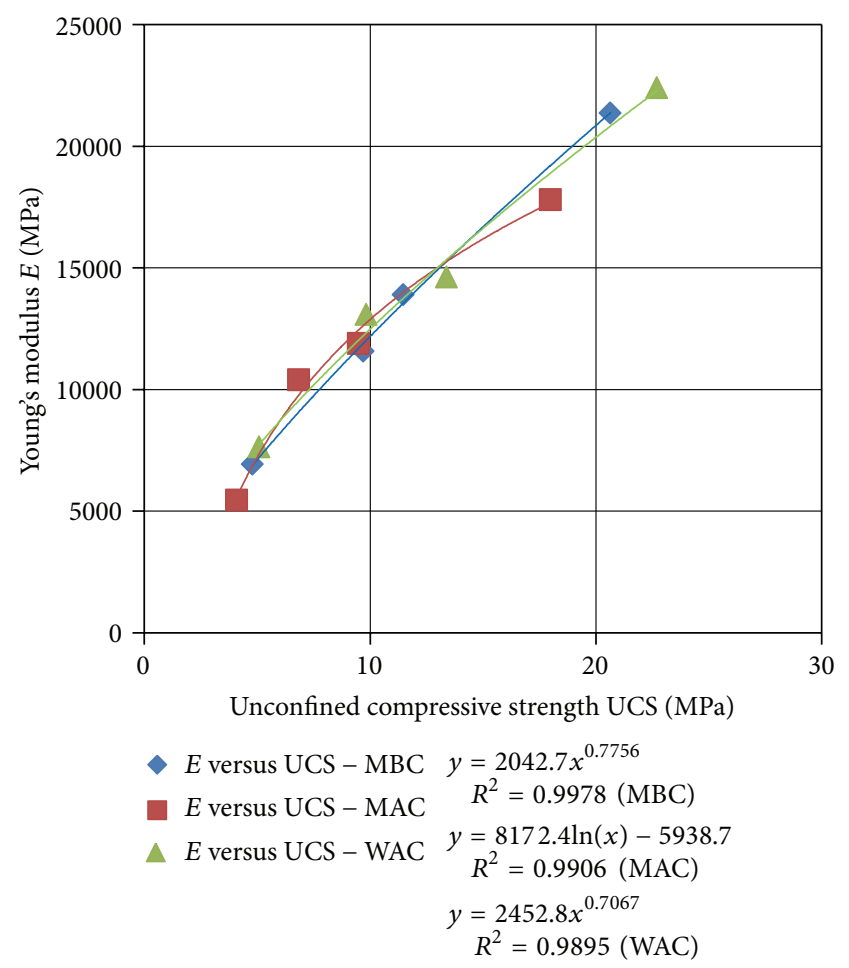

FIgURE 13: Relationship between Young's modulus $(E)$ and unconfined compressive strength (UCS) for increasing cement content.

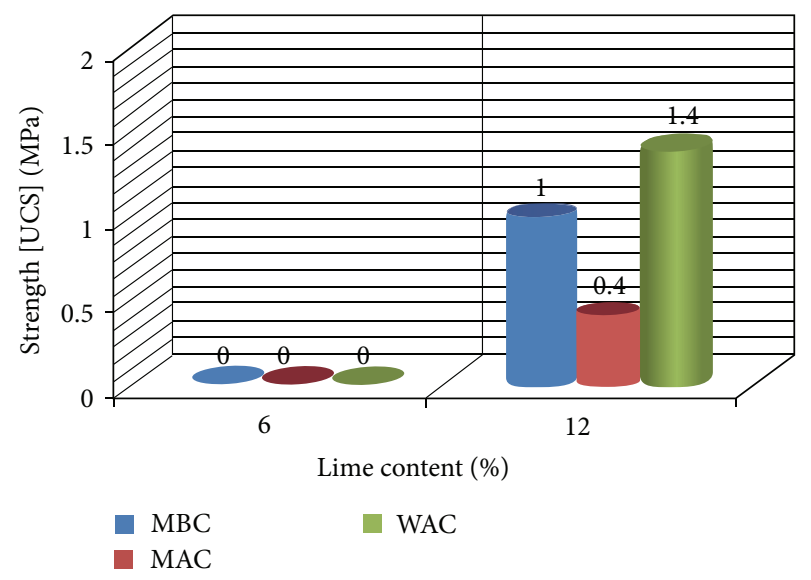

FIGURE 14: UCS of different lime contents (dry durability conditions).

failed in the bath after being cured for seven days and ovendried. The cubes just crumbled after being submerged into the soaking bath, before they could be tested.

3.3.3. Lime and Fly-Ash Stabilization $(6+12 \%$ and $12+12 \%$ Lime and Fly Ash). The addition of fly ash to lime improved the UCS of the stabilized WDA specimens (Figures 14 and 15). UCS of $0 \mathrm{MPa}$ for $6 \%$ lime content for all the curing methods increased from 0.3 to $0.55 \mathrm{MPa}$ for the $\mathrm{MBC}$ and MAC curing. Also UCS of 0.4 to $1.0 \mathrm{MPa}$ for the MBC and MAC curing increased to 0.7 to $1.25 \mathrm{MPa}$. The water curing (WAC) did not

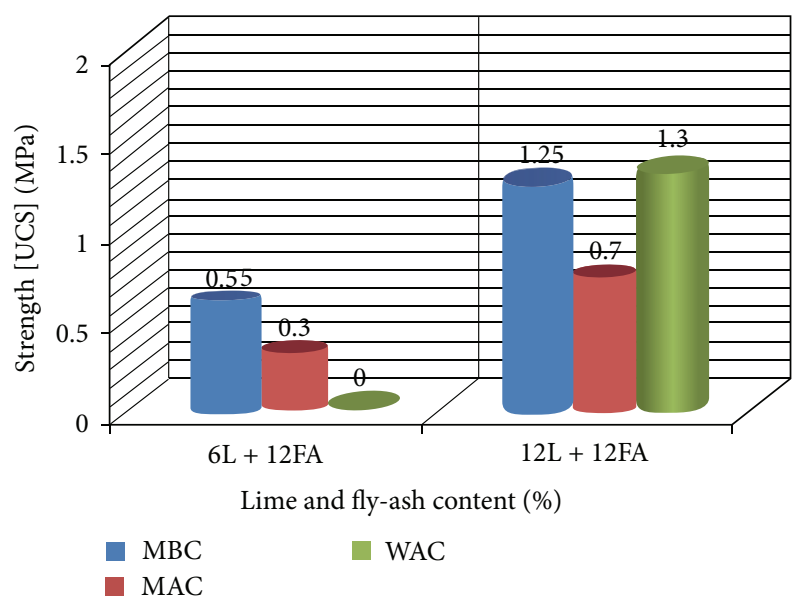

FIGURE 15: UCS of different lime and fly ash contents (dry durability conditions).

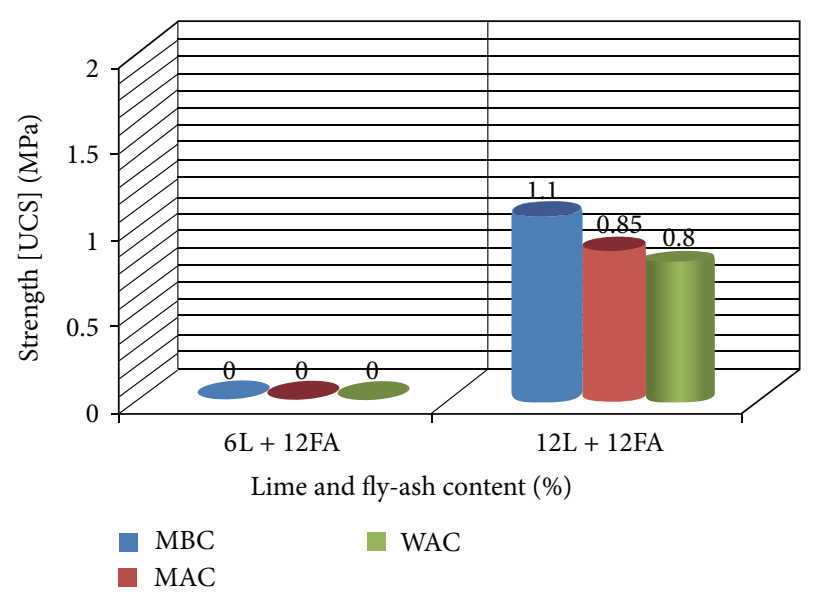

FIgURE 16: UCS of different lime and fly-ash contents (soaked durability conditions).

give satisfactory result, especially for the soaked durability condition (Figure 16). The membrane curing is the best method that can be used for the lime and fly-ash stabilization of WDA. Addition of fly ash to lime would perform better for highly weathered dolerite aggregates with a higher clay mineral or smectite (expansive clay minerals frequently present in WDA [6]) content. The reuse of waste fly ash with lime for WDA stabilization is recommended to be practiced along with cement stabilization. This would enhance utilising of local resources, improve energy management, and reduce land disposal and environmental sustainability.

\subsection{Effect of Wet-Dry (W-D) Cycles and Binder Proportion} Variations on Durability. The results of W-D cycles for a wide range of binder (cement, lime, and fly ash) proportions, for the cured stabilized weathered dolerite aggregates (WDA), are summarized in Tables 9 and 10. Studying the effect of W-D cycles on unconfined compressive strength (UCS) of cement stabilized specimens in Table 9 reveals 22\% loss in strength after $12 \mathrm{~W}$-D cycles for $8 \%$ cement stabilization. 
TABLE 9: Wet-dry cycles for cement stabilization.

\begin{tabular}{ccccc}
\hline W-D cycles & Binder proportion (\%) & UCS (MPa) & Strain (\%) & Young's modulus [E] (MPa) \\
\hline \multirow{4}{*}{0} & $4 \mathrm{C}$ & 5.1 & 0.067 & 7612 \\
& $8 \mathrm{C}$ & 9.8 & 0.075 & 13067 \\
& $12 \mathrm{C}$ & 13.4 & 0.092 & 14565 \\
12 & $16 \mathrm{C}$ & 22.7 & 0.101 & 22475 \\
\hline & $4 \mathrm{C}$ & 3.2 & 0.048 & 6667 \\
& 8C & 7.6 & 0.075 & 10133 \\
& $12 \mathrm{C}$ & 10.9 & 0.090 & 12111 \\
& $16 \mathrm{C}$ & 18.5 & 0.095 & 19474 \\
\hline
\end{tabular}

C: cement; UCS: unconfined compressive strength.

TABLE 10: Wet-dry cycles for lime and fly-ash stabilization.

\begin{tabular}{|c|c|c|c|c|}
\hline W-D cycles & Binder proportion (\%) & $\mathrm{UCS}(\mathrm{MPa})$ & Strain $(\%)$ & Young's modulus $[E](\mathrm{MPa})$ \\
\hline \multirow{8}{*}{0} & $6 \mathrm{~L}+6 \mathrm{FA}$ & 0.34 & 0.005 & 6800 \\
\hline & $6 \mathrm{~L}+12 \mathrm{FA}$ & 0.55 & 0.006 & 9167 \\
\hline & $6 \mathrm{~L}+18 \mathrm{FA}$ & 0.72 & 0.006 & 12000 \\
\hline & $6 \mathrm{~L}+24 \mathrm{FA}$ & 1.00 & 0.007 & 14286 \\
\hline & $12 \mathrm{~L}+12 \mathrm{FA}$ & 1.25 & 0.007 & 17857 \\
\hline & $12 \mathrm{~L}+18 \mathrm{FA}$ & 1.35 & 0.009 & 15000 \\
\hline & $12 \mathrm{~L}+24 \mathrm{FA}$ & 1.40 & 0.010 & 14000 \\
\hline & $12 \mathrm{~L}+30 \mathrm{FA}$ & 1.40 & 0.010 & 14000 \\
\hline \multirow{8}{*}{12} & $6 \mathrm{~L}+6 \mathrm{FA}$ & 0.13 & 0.002 & 6500 \\
\hline & $6 \mathrm{~L}+12 \mathrm{FA}$ & 0.35 & 0.005 & 7000 \\
\hline & $6 \mathrm{~L}+18 \mathrm{FA}$ & 0.43 & 0.007 & 6143 \\
\hline & $6 \mathrm{~L}+24 \mathrm{FA}$ & 0.62 & 0.007 & 8857 \\
\hline & $12 \mathrm{~L}+12 \mathrm{FA}$ & 0.90 & 0.008 & 11250 \\
\hline & $12 \mathrm{~L}+18 \mathrm{FA}$ & 0.95 & 0.009 & 10556 \\
\hline & $12 \mathrm{~L}+24 \mathrm{FA}$ & 1.05 & 0.010 & 10500 \\
\hline & $12 \mathrm{~L}+30 \mathrm{FA}$ & 1.05 & 0.010 & 10500 \\
\hline
\end{tabular}

L: lime, FA: fly ash; UCS: unconfined compressive strength.

The loss in strength was higher $(36.8 \%)$ for $4 \%$ cement stabilization as expected, while strength losses of $18.9 \%$ and $18.5 \%$ for $12 \%$ and $16 \%$ cement stabilization, respectively, can be considered close enough to the $22 \%$ loss obtained for $8 \%$ cement stabilization. It is therefore economically plausible to recommend $8 \%$ cement stabilization for WDA for pavement construction. The effect of W-D cycles on UCS of lime and fly ash stabilized specimens can be deduced from Table 10. The average loss in strength after $12 \mathrm{~W}$-D cycles for specimens stabilized with $6 \mathrm{~L}+6 \mathrm{FA}$ (6\% lime and $6 \%$ fly ash), $6 \mathrm{~L}+$ $12 \mathrm{FA}, 6 \mathrm{~L}+18 \mathrm{FA}$, and $6 \mathrm{~L}+24 \mathrm{FA}$ was $44 \%$ while the average loss in strength after $12 \mathrm{~W}$-D cycles for specimens stabilized with $12 \mathrm{~L}+12 \mathrm{FA}, 12 \mathrm{~L}+18 \mathrm{FA}, 12 \mathrm{~L}+24 \mathrm{FA}$, and 12L + 30FA was $27 \%$. This signifies that WDA stabilized with $12 \%$ lime in combination with fly ash would perform better than WDA stabilized with $6 \%$ lime in combination with fly ash. $12 \mathrm{~L}+$ 12FA stabilized WDA in particular had $28 \%$ loss in strength after $12 \mathrm{~W}$-D cycles, while the other fly ash combinations with
$12 \%$ lime had loss in strength values close to that of $12 \mathrm{~L}+$ 12FA. From Table 10, Young's Modulus $(E)$ value for $12 \mathrm{~L}+$ 12FA was higher than those of all the other binder (lime and fly ash) combinations.

\subsection{Effect of Initial Moulding Water Content on Mobilised UCS}

3.5.1. 4\% Cement Content. The effects of initial moulding water content on mobilised UCS for 4 percent cement are shown in the Figures 17 and 18. The strength of the cement stabilised WDA initially increased to a maximum at 12 percent and then starts decreasing with increasing water content. This was the case for both the dry and soaked durability conditions.

3.5.2. 12\% Cement Content. Figures 19 and 20 also indicate that the strength of the cubes initially increased to a maximum value at 12 percent water content and then decreased as 


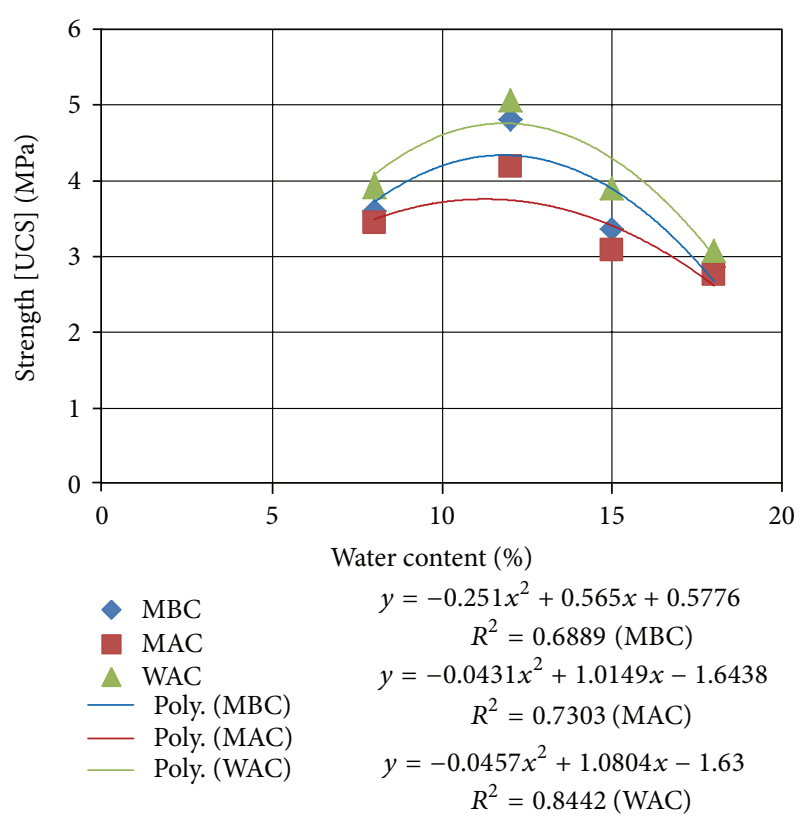

FIGURE 17: UCS for different water contents (4\% cement) (dry durability condition).

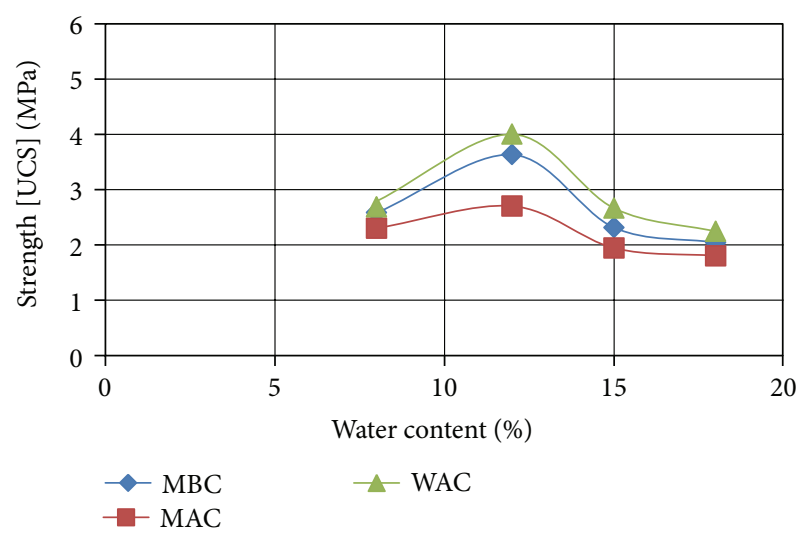

FIGURE 18: UCS for different water contents (4\% cement) (soaked durability condition).

the water content increases. The strength-water content relationship is similar for both the $4 \%$ and $12 \%$ cement content. However 12 percent cement contents gave higher strengths than the 4 percent cement as expected. The configuration of the graphs shows that when the water content is increased beyond 15 percent, the rate of reduction in strength is suppressed. Equation (4) is the relationship between UCS and water content for $12 \%$ cement content. A similar expression was also obtained for the case of $4 \%$ cement stabilization of WDA:

$$
\begin{aligned}
\mathrm{UCS}= & -0.099 \mathrm{~W}^{2}+2.2240 \mathrm{~W} \\
& +4.2866 \quad\left(R^{2}=0.7576\right) .
\end{aligned}
$$

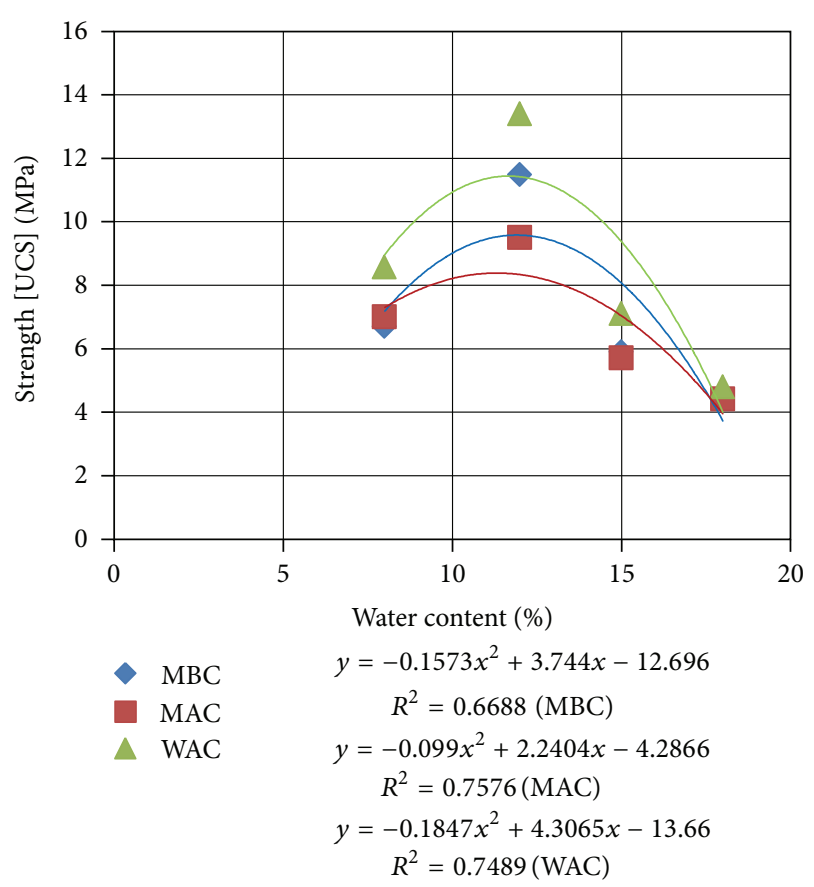

FIGURE 19: UCS for different water contents (12\% cement) (dry durability condition).

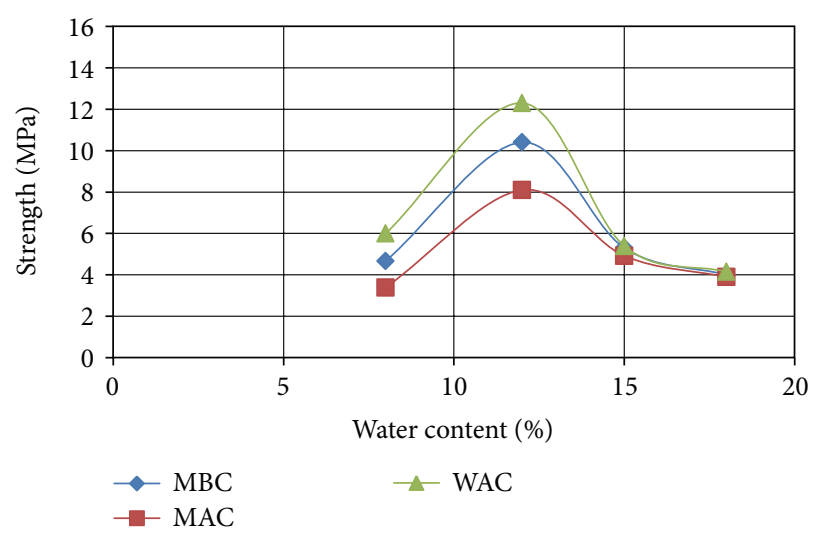

FIGURE 20: UCS for different water contents (12\% cement) (soaked durability condition).

\section{Conclusions}

Mineralogy for the weathered dolerite aggregates (WDA) samples with calcic plagioclase as the predominant mineral is comparable to those obtained by [20] for dolerites in South Africa. The UCS for the stabilized WDA increased with increase in cement content for the three curing methods with generally higher strength values for water curing (WAC). The values of the UCS for the membrane curing (MBC) for the various cement percentages can be seen to be close to those for the water curing (WAC). It was observed that durability generally increased with increase in cement content for all the curing methods. Equation (3) with a coefficient of determination of 0.9978 is proposed as an approximate expression 
to predict the Young's modulus of stabilized WDA from the unconfined compressive strength. The addition of fly ash to lime improved the UCS of the stabilized WDA specimens. UCS of $0 \mathrm{MPa}$ for $6 \%$ lime content for all the curing methods increased to between 0.3 and $0.55 \mathrm{MPa}$ for the $\mathrm{MBC}$ and $\mathrm{MAC}$ curing. Also UCS of 0.4 to $1.0 \mathrm{MPa}$ for the MBC and MAC curing increased to between 0.7 and $1.25 \mathrm{MPa}$. The membrane curing is the best method that can be used for the lime and fly-ash stabilization of WDA. The reuse of waste fly ash with lime for WDA stabilization is recommended to be practiced along with cement stabilization. This would enhance utilising of local resources, improved energy management, reduced land disposal and environmental sustainability. For class B (Interurban collector and major rural roads) pavement construction, addition of $8 \%$ cement was recommended for road base construction with stabilized WDA. This would give 7.0-9.0 MPa UCS in the range of $\mathrm{C} 2$ crushed stone designation $[19,21]$. Also the addition of $12+12 \%$ Lime and Fly Ash was recommended for road subbase construction with stabilized WDA. This would give 1.25-3.0 MPa UCS in the range of $\mathrm{C} 3$ crushed stone designation.

\section{Conflict of Interests}

The authors declare that there is no conflict of interests regarding the publication of this paper.

\section{Acknowledgments}

The authors would like to acknowledge Moipone Melamu and Phethile Nkosi for their involvement in data collection.

\section{References}

[1] TNZ M4, Specification for Base Course Aggregate, Transit New Zealand, Wellington, New Zealand, 2006, http://www.nzta.govt .nz/resources/basecourse-aggregate/docs/basecourse-aggregate.pdf.

[2] G. Arnold, S. Werkemeister, and D. Alabaster, "Performance tests for road aggregates and alternative materials," Research Report 335, Land Transport, Wellington, New Zealand, 2010, http://www.nzta.govt.nz/resources/research/reports/335/docs/ 335.pdf.

[3] H. Akbulut and C. Gürer, "Use of aggregates produced from marble quarry waste in asphalt pavements," Building and Environment, vol. 42, no. 5, pp. 1921-1930, 2007.

[4] P. Paige-Green, "The durability of stabilised materials. CSIR built environment, Pretoria, South Africa," in Proceedings of the 12th International Conference of International Association for Computer Methods and Advances in Geomechanics (IACMAG '08), pp. 3787-3793, Goa, India, 2008.

[5] D. X. Xuan, L. J. M. Houben, A. A. A. Molenaar, and Z. H. Shui, "Mechanical properties of cement-treated aggregate materiala review," Materials and Design, vol. 33, no. 1, pp. 496-502, 2012.

[6] E. Kleyn, A. Bergh, and P. Botha, "Practical implications of the relation between the clay mineral content and the plasticity Index of dolerite road construction material," Journal of the South African Institution of Civil Engineering, vol. 51, no. 1, pp. $2-5,2009$.
[7] D. J. Sloane, "Some physical properties of dolerite," Tech. Rep. Report 1991/22, Division of Mines and Mineral Resources Tasmania, 1991, http://www.mrt.tas.gov.au/mrtdoc/dominfo/download/UR1991_22/UR1991_22.pdf.

[8] P. Paige-Green and F. Netterberg, "Cement stabilization of road pavement materials: laboratory testing programme phase 1 ," Tech. Rep., CSIR for Cement and Concrete Institute, 2004, http://hdl.handle.net/10204/3142.

[9] E. G. Kleyn and A. O. Bergh, "Some practical aspects regarding the handling of dolerite for base and sub-base construction. Partnership for research and progress in transportation," in Proceedings of the 27th Southern African Transport Conference (SATC '08), pp. 98-107, Pretoria, South Africa, 2008.

[10] B. Alemue, Engineering Geological Characterisation of Granular Sub-Base Using Lime-A Case Study of Ambo-Gedo Road Project, LAP LAMBERT Academic Publishing, Saarbrücken, Germany, 2010.

[11] D. N. Little and S. Nair, "Recommended practice for stabilisation of subgrade soils and base materials," Tech. Rep. NCHRP Web-Only Document 144, National Cooperative Highway Research Program, Transportation Research Board, 2009, http://onlinepubs.trb.org/onlinepubs/nchrp/nchrp_w144.pdf.

[12] M. Veelen and A. T. Visser, "The performance of unpaved road material using soil stabilisers," Journal of the South African Institution of Civil Engineering, vol. 49, no. 4, pp. 2-9, 2007.

[13] E. G. Akpokodje, "A method of reducing the cement content of two stabilized Niger delta soils," Quarterly Journal of Engineering Geology, vol. 19, no. 4, pp. 359-363, 1986.

[14] P. T. Sherwood, Soil Stabilization with Cement and Lime, State of the ART Review, HMSO Press, London, UK, 1995.

[15] A. A. Al-Rawas and M. F. A. Goosen, Soils-Recent Advances in Characterization and Treatment, Taylor \& Francis Group, Balkema, London, UK, 2006.

[16] K. M. A. Hossain, M. Lachemi, and S. Easa, "Stabilized soils for construction applications incorporating natural resources of Papua New Guinea," Resources, Conservation and Recycling, vol. 51, no. 4, pp. 711-731, 2007.

[17] L. Chen and D.-F. Lin, "Stabilization treatment of soft subgrade soil by sewage sludge ash and cement," Journal of Hazardous Materials, vol. 162, no. 1, pp. 321-327, 2009.

[18] TMH 1, Standard Methods of Testing Road Construction Materials, Technical Methods for Highways (TRH 1), National Institute for Transportation and Road Research, Pretoria, South Africa, 1986.

[19] TMH 13, Cementitious Stabilizers in Road Construction, Technical Methods for Highways (TRH 13), National Institute for Transportation and Road Research, Pretoria, South Africa, 1986.

[20] N. Khoury and M. M. Zaman, "Durability of stabilized base courses subjected to wet-dry cycles," International Journal of Pavement Engineering, vol. 8, no. 4, pp. 265-276, 2007.

[21] F. G. Bell and C. A. Jermy, "The geotechnical character of some South African dolerites, especially their strength and durability," Quarterly Journal of Engineering Geology and Hydrogeology, vol. 33 , no. 1, pp. 59-76, 2000. 

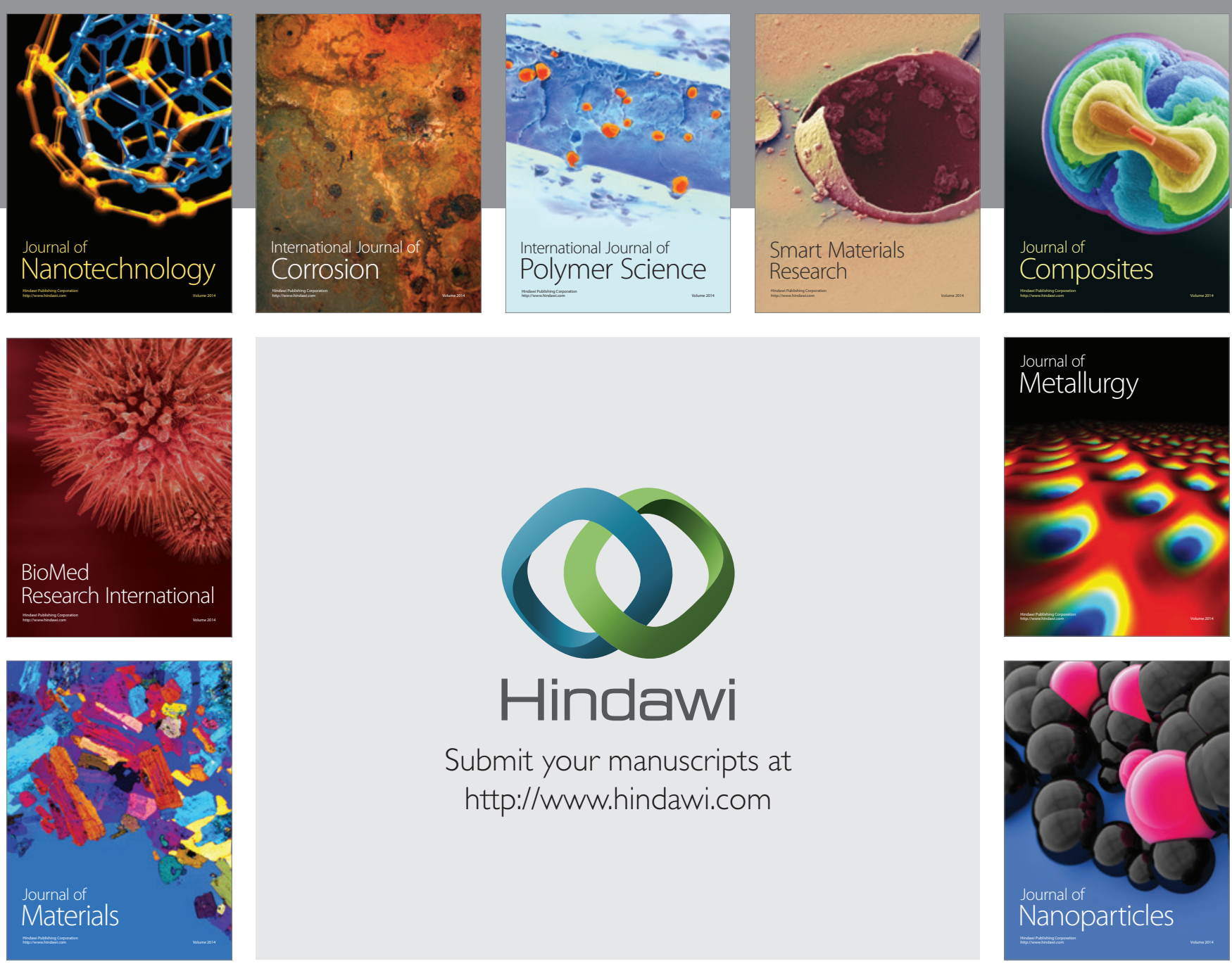

Submit your manuscripts at http://www.hindawi.com
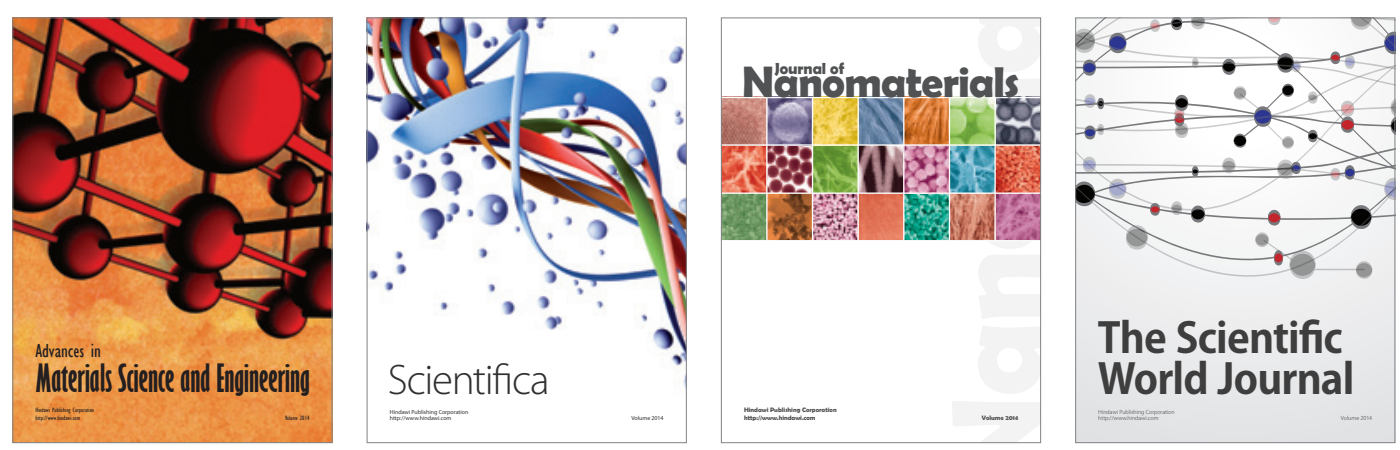

\section{The Scientific World Journal}
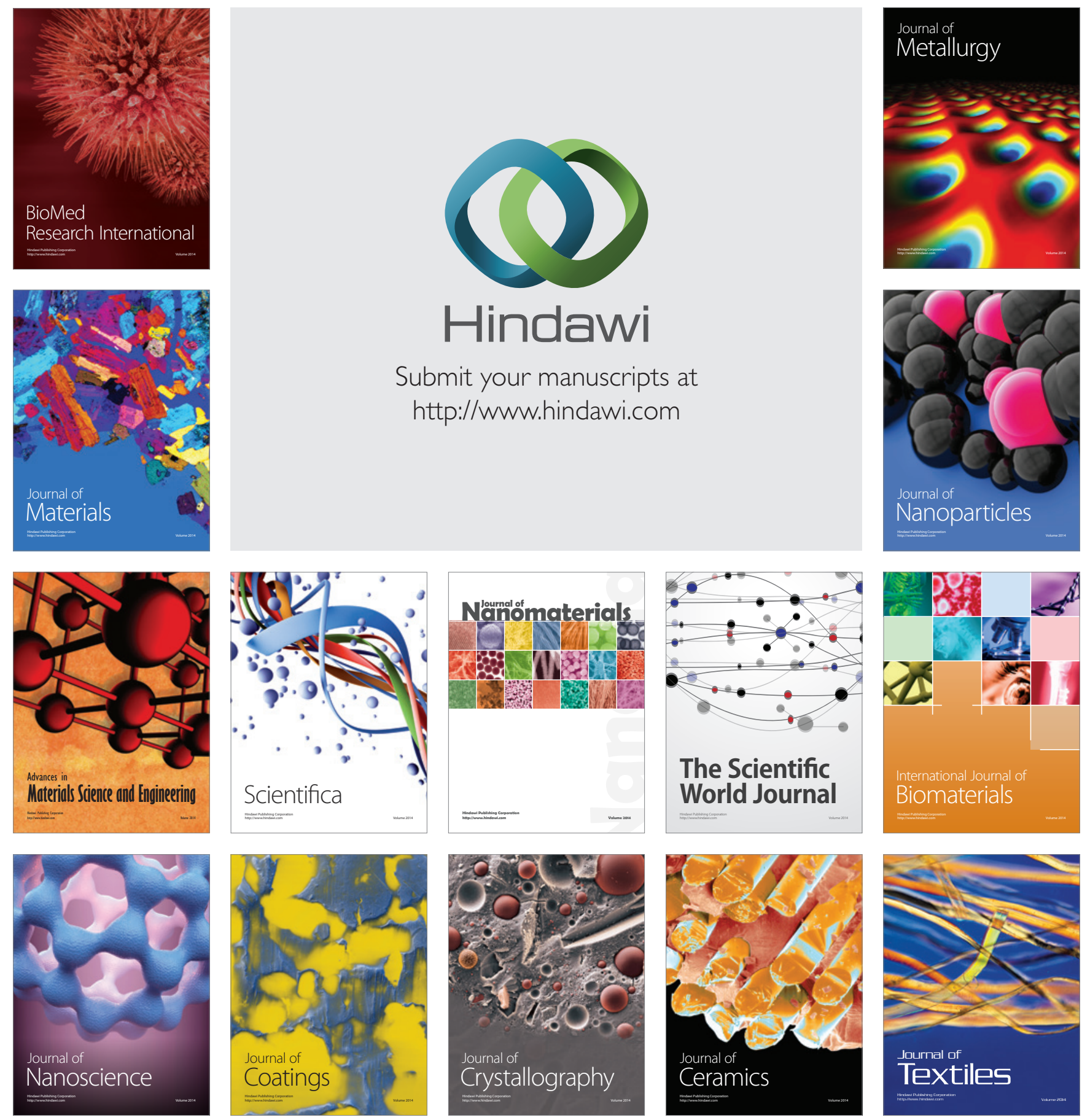